\title{
Must we live with inclusion bodies?
}

\section{Journal Article}

\section{Author(s):}

Schein, Catherine $\mathrm{H}$.

Publication date:

1993

\section{Permanent link:}

https://doi.org/10.3929/ethz-b-000422990

\section{Rights / license:}

In Copyright - Non-Commercial Use Permitted

Originally published in:

Protein Engineering, Design \& Selection 6(Supplement), https://doi.org/10.1093/protein/6.Supplement.29 


\section{PROTEIN FOLDING}

IN VIVO 
Must we live with inclusion bodies?

Catherine H. Schein

Swiss Federal Institute of Technology

CH8092 Zürich Switzerland

High expression levels of recombinant proteins do not necessarily mean that the protein must be in inclusion bodies (IBS). This talk will describe some of the more successful solutions to the problem of expressing successful solutions to the problem of

Many groups prefer to express proteins in an insoluble Many groups prefer to express proteins in an insolub form, primarily because of the advantages listed
Table 1. The disadvantages are often ignored.

\begin{tabular}{|c|c|}
\hline Advantages & Disadvantages \\
\hline $\begin{array}{l}\text { High expression level> } \\
\text { reduced fermentation costs }\end{array}$ & $\begin{array}{l}\text { Refolding shifts problems and } \\
\text { costs downstream. }\end{array}$ \\
\hline $\begin{array}{l}\text { Production can be monitored } \\
\text { with PAGE or immunoblotting }\end{array}$ & $\begin{array}{l}\text { Production cannot be monitored } \\
\text { directly by activity. }\end{array}$ \\
\hline $\begin{array}{l}\text { Cytoplasmic proteins are washed } \\
\text { away, simplifying purification. } \\
\text { " } 95 \% \text { " purity can be quickly } \\
\text { achieved }\end{array}$ & $\begin{array}{l}\text { The other "5g" contaminants are } \\
\text { hydrophobic, poorly soluble } \\
\text { membrane proteins and cell } \\
\text { wall fragments }\end{array}$ \\
\hline $\begin{array}{l}\text { The major contaminants are } \\
\text { oligomers and misfolded or } \\
\text { proteolyzed forms of the } \\
\text { desired protein }\end{array}$ & $\begin{array}{l}\text { Separation of multiple forms of } \\
\text { the same protein is the most } \\
\text { difficult purification step. }\end{array}$ \\
\hline $\begin{array}{l}\text { The } \mathrm{pL} \text { promotor with } \mathrm{T} \\
\text { induction often yields protein } \\
\text { where other systems fail }\end{array}$ & $\begin{array}{l}\text { If the protein does not refold } \\
\text { well, another expression system } \\
\text { will still be needed. }\end{array}$ \\
\hline
\end{tabular}

When to use inclusion bodies: The most successful IB purification schemes have been for small flexible proteins. IB purifications are often favoured by university labs with no access to fermentors, as large amounts of protein can be produced in shaker flask culture. Increasing cell density per liter does not improve economics, as the limiting factor in the purification is the volume required for refolding. IBs purification is the volume required for refolding. IBs bacteria that are not producible by secretion (eg.,

histones). In addition, no successful system for producing membrane proteins in a soluble form has been described.

The difficulties of refolding larger proteins economically have proved prohibitive. Animal cell cultivation was more economical for production of tPA than production in IBs because the purification costs were so high (Datar, Cartwright, \& Rosen, MS in prep.) Integration of upstream and dowstream processing The choice of protein expression system should not be left to the fermentation group. Their emphasis is usually on with little regard to the downstream purification. is important to keep all options open at the beginn fo the cloning becinning hard to change anything hard to change anything. Although protein purification is complex, lt should be thought of as a stream that starts at the fermentor and ends in vials of purified roduct.

The only valid yield figure for a process is the amount of usable protein produced per liter of culture fluid. As simple as this definition sounds, real yield figures tend to be elusive. Several groups, often in different cities, take part in the purification. True costs per mg protein are also difficult to calculate at the lab scale as labor costs are often underestimated.

Secretion systems In some cases, the desired protein is too toxic or sensitive to proteolysis to be expressed intracellularly in a soluble form. Secretion from $E$. coli has been very successful for heterologous protein that are secreted in their original environment, including human growth hormone, 1 "humanized" antibodies, 2 and bacterial ${ }^{3}$ and mammalian ${ }^{4}$ RNases. Secretion from other bacterial species, yeasts, and fungi is also possible.

Yields in secretion systems can be increased by growing the cells to high densities and by using host strains selected for low protease production. Optimizing the growth temperature, reducing air bubbling and adding protease inhibitors or detergents to the medium can also help to increase protein in the supernatant.
Expressing soluble proteins intracellularly. One of the easiest and most generally applicable method to increase the protein in the soluble fraction is to reduce the $\mathrm{E}$. coli growth temperature. ${ }^{5}$ Table 2 lists a few proteins that are more soluble when produced in $E$. $30^{\circ} \mathrm{C}$ or less.

\begin{tabular}{|c|c|c|}
\hline Erotein: & Promotor: & Reference: \\
\hline $\begin{array}{l}\text { Mammalian: } \\
\text { human Interferon- } \alpha 2 \\
\text { human Interferon- } \gamma \\
\text { murine Mx } \\
\text { human Interferon- } \beta \\
\text { human transforming } \\
\text { growth factor- } \beta \\
\text { rabbit muscle glycogen } \\
\text { phosphorylase } \\
\text { murine cAMP-dependent } \\
\text { protein kinase } \\
\text { (catalytic subunit) } \\
\text { plant: } \\
\text { radish } 3 \text {-oH-3-methyl } \\
\text { glutarylcoenzyme A } \\
\text { reductase } \\
\text { rice lipoxygenase L-2 } \\
\text { yeast } \alpha-g l u c o s i d a s e ~ P 1 \\
\text { Bacteria: } \\
\text { T4 DNA polymerase } \\
\text { Ricin A-chain }\end{array}$ & $\begin{array}{l}\text { T7, colE1, } \\
\text { Amp } \\
\text { PTrp } \\
\text { PTrp } \\
\text { pTrp } \\
\text { pTrp } \\
\text { pTrplac } \\
\text { hybrid, T7 } \\
\text { T7 } \\
\text { T7 } \\
\text { T7 } \\
\text { tac-hybrid } \\
\text { pL, ptac } \\
\text { pL,pTrp, } \\
\text { lacuv5 } \\
\text { trc } \\
\text { phage } \\
\text { promotor } \\
\text { tandem } \\
\text { lpp/lac-OmpA }\end{array}$ & 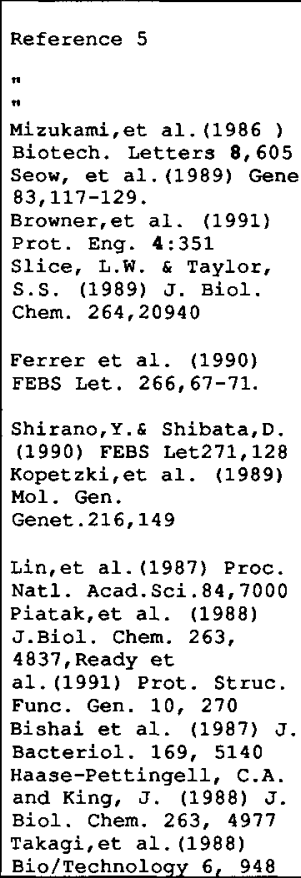 \\
\hline
\end{tabular}

changes in the protein sequence. In some cases, one might consider altering the protein sequence to obtain a protein with better solubility characteristics. For example, discrete changes in human hemoglobin make a more stable protein for use in blood substitutes, and the solubility of insulin preparations can be altered by changing residues at the oligomer interface. The in vivo and in vitro aggregation tendencies of a protein vivo and in vitro aggregation

certain proteins remain soluble under all growth Certain proteins remain soluble under all growth
conditions. Several examples of a single amino acid change rendering a protein more ${ }^{6}$ or less $^{7}$ likely to form IBs have been found.

In conclusion, there are now many ways to express large amounts of protein in a soluble form in $E$. coli. We can for the most part control the solubility of proteins produced, so we no longer need to live with IBs unless we want to.

References

${ }^{1}$ Chang, J. Y-H., Pai, R.C. Bennett, W.F., and Bochner, B.R. 1989 Biochem. Soc. Trans. 17, 335-337.

${ }^{2}$ Carter, P., Kelley, R.F., Rodrigues, M.L., Snedecor, B., Cavarrubias, M. Velligan, M.D., Wong, W.L.T., Rowland, A.M., Kotts, C.E., Carver, M.E., Yang, M., Bourell, J.H., Shepard, H.M., \& Henner, D. (1992) Biot/technology 10, 163-167.

${ }^{3}$ Hartley, R.W. (1988) J. Mol. Biol. 202, 913-915.

${ }^{4}$ Schein, C.H., Boix, E., Haugg, M., Holliger, K.P., Hemmi, S., Frank, G.

\& Schwalbe, H.(1992) The Biochemical Journal 283,137-144.

${ }^{5}$ Schein, C.H. and Noteborn, M.H.M (1988) Bio/Technology 6, 291-294.

6Rinas, U., Tsai, L.B., Lyons, D., Fox, G.M., Stearns, G., Fieschko, J

Fenton, D., and Bailey, J.E. (1992) Bio/Technology 10, 435-440.

${ }^{7}$ Wetzel, R., Perry, J.L. \& Veilleux, C.(1991) Bio/technology 9,731-737,

Mitraki, A., Fane, B., Haase-Pettingell, C., Sturtevant, J., \& King, J.

(1991) Science 253, 54-58. 